\title{
LOGICO-HYPOTHETICO-VERIFICATIF SEBAGAI METODA ILMIAH \\ DALAM MENCARI \\ ILMU PENGETAHUAN YANG BENAR
}

\author{
Acep Rohendi \\ Universitas BSI Bandung \\ Email : arohendi1209@gmail.com
}

\begin{abstract}
Man's journey in finding the truth to overcome problems in his life, discussing various theories / flows in his time and continually developing complementary. Correlation of truth flow that emphasizes truth is in accordance with what is expected by humans or human experience. Arguments that are not in accordance with facts are not truth. Something is considered to be something that is in accordance with the facts (empirical). Contrary to this theory is the theory of Consistency, which confirms something that supports the truth that was previously questioned. The scientific method as a path of truth is used to get knowledge using Correspondence theory and Consistency theory. Combined theories of correspondence and consistency theory produce the term "Logico-hypotheticoverificatif" with all its advantages and disadvantages.
\end{abstract}

Keywords: Truth, Correspondence, Consistency

\section{PENDAHULUAN}

Ada perbedaan yang mencolok antara filsafat modern, khususnya yang dianut oleh Barat, dengan filsafat Islam dalam menentukan dasar pandangan; yaitu pada filsafat modern berorientasi kepada manusia, jadi bersifat antroposentrik (berkisar sekitar manusia); sedang pada filsafat Islam berorientasi kepada Tuhan, jadi bersifat teosentrik (berkisar sekitar Tuhan). ${ }^{1}$

Peletak dasar pandangan antroposentrik dalam filsafat modern dan kebudayaan Barat, menurut Marcel A. Boisard, adalah Rene Descartes dengan filsafat rasionalnya. Pandangan semacam ini mewarnai pemikiran sehari-hari di Barat, khususnya di benua Eropa. Faktor ini pulalah yang menyebabkan adanya

\footnotetext{
${ }^{1}$ Abdul Qodir Djaelani, Filsafat Islam, Surabaya : PT.Bina Ilmu,1993,hlm.35.
} 
pemisahan dan perbedaan yang mendalam antara Barat dan Timur (khususnya Islam). ${ }^{2}$

Antroposentrik, berarti menjadikan manusia sebagai pusat batu ujian tentang kebenaran dan kepalsuan, memberikan kepada manusia sebagai pemberi kriteria tentang nilai baik dan buruk, indah dan jelek. Karenanya ia menentang hal-hal yang bersifat teosentrik; ukuran yang berasal dari Tuhan. ${ }^{3}$

Secara historis sepuluh abad lamanya, dalam Abad Pertengahan, pemikiran filosofi dan ilmu pengetahuan berdasarkan rasio defresi oleh kebenaran teologis yang berdasarkan iman. Semangat untuk membebaskan manusia dari keterbelengguan teologis muncul pada masa "Renaisance" (kelahiran kembali). Kelahiran filsafat Yunani kuno yang otonom lewat mempelajari kembali karyakarya yang selama ini disembunyikan dan dimonopoli kalangan geraja saja ${ }^{4}$.

Munculnya Renaisance tidak bisa dilepaskan begitu saja dari sumbangan para filosof Islam dalam menterjemahkan karya-karya klasik Yunani ke dalam bahasa Arab. Karya itulah yang nantinya dipelajari oleh dunia Barat.. Sejarah mencatat bahwa perkembangan ilmu pengetahuan di dunia Islam, telah maju lebih dahulu sebelum dunia Barat memperoleh "pencerahan". Renaisance yang kemudian diikuti oleh masa pencerahan (Aufklarung) menjadi titik tolak modernisme di mana ilmu pengetahuan, filsafat, dan ideologi berkembang demikian pesatnya. Otonomi manusia (antroposentris) menjadi roh zaman moderen. ${ }^{5}$

Penggunaan rasio dalam filsafat moderen ini tidak bisa dilepaskan dari pemikiran Rene Descartes (15-96-1860), filosof yang mampu menggugah rasio manusia yang telah dijadikan hamba sahaya keimanan selama kurang lebih seribu tahun. Pemikirannya berpengaruh terhadap aliran filsafat yang cukup besar bagi perkembangan ilmu pengetahuan, yaitu Rasionalisame. Pemikirannya mendapat tantangan keras dari David Hume, John Locke dan George Berkeley sebagai

\footnotetext{
${ }^{2}$ Abdul Qodir Djaelani, Op.Cit.,hlm.38.

${ }^{3}$ Ali Syari'ati, Kritik Islam Atas Marxisme, Bandung : Mizan,1983,hlm.56

${ }^{4}$ Donny Gahral Adian, Menyoal Obyektifitas Ilmu Pengetahuan : Dari David Hume sampai Thomas Kuhn, Cet.1, Jakarta : Teraju, 2002,hlm.10.

${ }^{5}$ Ibid.
} 
penganut paham Empirisme. Yaitu aliran filsafat yang menyatakan pengetahuan hanya didapat melalui pengalaman empiris bukan semata-mata penalaran deduksi. $^{6}$

Pertentangan berlangsung terus sampai muncul filosof Jerman bernama Immanuel Kant (1724-1804), yang berhasil membuat sintesis antara Rasionalisme dengan Empirisme. Menurut Khan kedua aliran tersebut sama-sama sangat ekstrim. Kant mengatakan bahwa rasio dan empiri adalah sama-sama sumber pengetahuan di mana kesan-kesan empiri dikonstruksikan oleh rasio manusia melalui kategori-kategori menjadi pengetahuan. Kant merupakan tokoh sentral dalam zaman moderen dengan perkataan yang cukup terkenal "sapede aude" (berani berfikir sendiri). ${ }^{7}$

Dalam abad 20 dunia empirisme yang obyektif dalam memandang pengetahuan tersebut mengalami puncaknya pada aliran filsafat Positivisme, yang dipelopori August Comte (1789-1857). Positivisme ini mendominasi wacana ilmu pengetahuan pada awal awal abad 20-an, dengan menetapkan kriteria-kriteria yang harus dipenuhi oleh ilmu-ilmu manusia maupun alam untuk disebut ilmu pengetahuan yangg benar. Kriteria-kriteria tersebut adalah eksplanatori dan prediktif. $^{8}$

Demi terpenuhi kriteria tersebut, maka ilmu-ilmu harus memiliki pandangan positivistik sebagai berikut : Pertama, obyektif. Teori-teori tentang semesta harus bebas nilai; kedua,fenomenalisme. Ilmu pengatahuan hanya bicara semesta yang teramati; ketiga, reduksionalisme. Semesta direduksi menjadi faktafakta keras yang teramati. Subastansi metafisis yang berada di balik gejala penampakan disingkirkan ; keempat, naturalisme alam semesta. Alam semesta adalah obyek-obyek yang bergerak secara mekanis seperti bekerjanya jam. ${ }^{9}$

Sebagai reaksi terhadap aliran filsafat moderen (Positivisme), muncul suatu kelompok yang menamakan diri Posmodernisme, yang bukan berarti pasca moderen, melainkan suatu terminologi yang mewakili pergeseran wacana

\footnotetext{
${ }^{6}$ Ibid, hlm.10 -11.

${ }^{7}$ Ibid,hlm.11.

${ }^{8}$ Ibid,hlm.12.

${ }^{9}$ Ibid.
} 
diberbagai bidang ilmu yang bereaksi keras terhadap modernisme yang terlampau mendewakan rasionalitas sehingga mengeringkan kehidupan dari kekayaan dunia batin manusia. Kritiknya yang paling mutakhir terhadap modernisme yang telah menjadikan sains, rasionalitas suatu telogi baru yang menghasilkan kebudayaan yang matematis, kalkulatif, monopolitik dan kering batin. Membatasi diri pada penalaran deduktifr maupun induktif, observasi dan bebas nilai, hal-hal yang justru tidak bisa diterapkan pada etika. ${ }^{10}$

Dengan adanya kritik terhadap ilmu barat moderen, dalam perkembangannya tersebut telah banyak yang menyanggah justru dari para pakar dari barat sendiri yang menyalahkannya. Di samping itu pada kenyataannya, ilmu Barat tersebut tidak mampu menyelesaikan masalah-masalah yang fundamental. Misalnya apa yang dimaksud dengan materi, energi dan ether. Di samping itu banyak kekurangan kekurangan dalam bidang kedokteran dengan munculnya penyakit-penyakit baru sementara yang lama belum ada solusinya. Demikian pula telah terjadi pemerkosaan terhadap alam yang semula bermaksud menundukkan alam. $^{11}$

Dengan kekaguman terhadap ilmu Barat tersebut, sebenarnya telah tersapu habis dengan segala kekurangan kekurangan yang fundamental dalam tubuh barat itu sendiri. Dan tidak ada kekuatan yang Self Corecting dalam tubuh ilmu Barat tersebut, serta terjadi inkonsistensi antar disiplin ilmu, sehingga bingung mana yang benar dan mana yang salah. Inilah kelemahan fundamental dari ilmu barat tersebut, dan kita tidak menyatakan mana yang benar dan mana yang salah. ${ }^{12}$ Semestinya menurut Claxton: "Science, viewed as a body of 'knowledge', is more accurately seen as a set of languages or 'maps' than an incontrovertible edifice of truth". ${ }^{13}$ (Ilmu pengetahuan, dipandang sebagai tubuh 'pengetahuan', lebih tepat

10 Ibid, hlm.14-15.

11 Herman Soewardi, Herman Soewardi, Roda Berputar Dunia Bergulir : Kognisi Bagu Tentang Timbul Tenggelammnya Sivilisasi, Bandung : Bakti Mandiri,2009,hlm.99

12 Ibid.

13 Claxton, Guy., "Science of The Times : A 2020 vision of education", dalam Ralph Levinson and, Jeff Thomas (ed.), Science to Day : Problem or crisis?, London : Taylor \& Francis e-Library, 2005,hlm.6. 
dilihat sebagai seperangkat bahasa atau 'peta' dari sebuah bangunan kebenaran yang tak terbantahkan).

Oleh karena itu, ilmu pengetahuan mestinya mencerminkan bangunan kebenaran, dengan mempergunakan metoda ilmiahnya, sebagai sarana mencari kebenaran ilmiah. Dengan tujuan menghasilkan generalisasi teori dalam rangka mengatasi masalah kehidupan dan kesejahteraan manusia. Bukan sebaliknya justru menimbulkan dampak bagi kehidupan manusia dan alam sekitar.

Pengertian metoda ilmiah sebagai metoda pencarian kebenaran ilmu pengetahuan, yang berbasis pada :

" its empirical nature (that is, it is based on observation and measurement). Another idea that enjoyed popularity in the early 20th century was that induction was the method of science. Put simplistically, induction entails gathering a series of observations and then analyzing them to arrive at a generalization. ${ }^{14}$

(alam empiris -yaitu, hal itu didasarkan pada pengamatan dan pengukuran. Gagasan lain yang menikmati popularitas di awal abad 20 adalah bahwa induksi adalah metode ilmu pengetahuan. Masukan menyederhanakan, induksi memerlukan pengumpulan serangkaian pengamatan dan kemudian menganalisis mereka untuk sampai pada generalisasi).

Penelitian dengan metoda ilmiah dengan berbasis empiris dan induksi telah menghasilkan generalisasi. Para ilmuwan dengan metoda ilmiahnya, telah melahirkan ilmu-ilmu.yang dihimpun dalam buku-buku, seperti dinyatakan oleh Thomas S.Kuhn :

"These textbooks expound the body of accepted theory, illustrate many or all of its successful applications, and compare these applications with exemplary observations and experiments". ${ }^{15}$

(Buku-buku tersebut menjelaskan tubuh teori yang diterima, menggambarkan sebagian atau hasil aplikasi yang sukses, dan membandingkan hasil aplikasi dengan atau semua aplikasi yang sukses, dan membandingkan aplikasi tersebut dengan observasi dan percobaan".

Dengan demikian ilmu-ilmu yang tertulis dalam buku-buku, seperti dikemukakan oleh Thomas S.Kuhn tersebut, merupakan ilmu pengetahuan

\footnotetext{
${ }^{14}$ Mac Ritchie, Finlay, Scientific Research as a Career, USA: CRC Press Taylor \& Francis Group,2011,hlm.23.

15 Kuhn, Thomas S., The Structure of Scientific Revolutions, Second Edition, Chicago : The University of Chicago ,1970,hlm.10.
} 
sebagai hasil penelitian dengan menggunakan metoda ilmiah, yang diterima oleh kalangan ilmuwan. Selanjutnya pandangan Thomas S.Kuhn, terhadap ilmu pengetahuan hasil penelitian tersebut, sebagai "normal science" atau paradigma. ${ }^{16}$

Norma science, "pada saat tertentu" diterima oleh masyarakat ilmiah sebagai landasan untuk penelitian lebih lanjut. Artinya Normal science bukan merupakan kebenaran mutlak, melainkan hanya kebenaran relatif yang setiap saat bisa diuji kembali untuk direvisi, diubah bahkan digantikan dengan teori baru ${ }^{17}$

Dari paparan tersebut disimpulkan bahwa ilmu pengetahuan yang berorientasi positivistik, telah digunakan manusia untuk mencari kebenaran mengenai alam semesta, terlepas dari segala kelebihan dan kekurangannya serta bagaimana implikasinya tersebut terhadap ilmuwan." Dengan latar belakang tersebut selanjutnya di bahas: metoda ilmiah sebagai jalan mendapatkan ilmu pengetahuan dan keterbatasan ilmu pengetahuan sebagai sarana mencari kebenaran.

\section{METODA ILMIAH SEBAGAI JALAN MENDAPATKAN ILMU PENGETAHUAN}

Ilmu menurut The Liang Gie berasal dari pengertian yang dicakup kata Inggris "Science". Istilah ilmu pengetahuan untuk terjemahan Science merupakan suatu pleonasme, yakni pemakaian lebih suatu perkataan yang sama secara bersamaan artinya. ${ }^{18}$ Dalam istilah Inggris "Science" terkadang diberi arti sebagai ilmu khusus yang lebih terbatas lagi sebagi pengetahuan sistematis mengenai dunia fisis atau material. "Science "sering kali juga dipakai untuk menunjuk gugusan ilmu-ilmu kealaman atau natural science. Science dalam arti natural science inilah yang biasanya dimaksud dalam ungkapan "sains dan teknologi". Namun, dalam praktek penulisan seperti dalam buku "Filsafat Ilmu" karya Tim

\footnotetext{
${ }^{16}$ Ibid.

${ }^{17} \mathrm{Ibid}$, hlm.66.

${ }^{18}$ The Liang Gie, Pengantar Filsafat Ilmu, Cet.VII, Yogyakarta: Liberty,2007,hlm.85.
} 
Dosen Filsafat Ilmu Fakultas Filsafat UGM, masih menggunakan terminologi "Ilmu Pengetahuan"19.

E. Saefullah Wiradipraja ${ }^{20}$, menjelaskan bahwa ilmu adalah kumpulan pengetahuan; namun tidak dapat dibalik bahwa kumpulan pengetahuan itu adalah ilmu. Dalam bahasa Indonesia "ilmu" terjemahan dari bahasa Inggris "Science", sedangkan "pengetahuan" terjemahan dari bahasa Inggris "knowlegde" ${ }^{21}$ Menurut Ahmad Tafsir" ${ }^{22}$ : "pengetahuan adalah keadaan tahu, pengetahuan adalah semua yang diketahui. Manusia ingin tahu sesuatu lantas ia mencari dan memperoleh pengetahuan. Pengetahuan ialah semua yang diketahui."

Kata ilmu sering diartikan sebagai sejumlah informasi yang diperoleh manusia melalui pengamatan, pengalaman (empirik) dan penalaran (rasio). Pengetahuan tentu berbeda dengan ilmu terutama dalarn pemakaiannya. Ilmu Iebih menitikberatkan pada aspek teoretisasi dan sejumlah pengetahuan yang diperoleh dan dimiliki manusia, sedangkan pengetahuan tidak mensyaratkan adanya teoretisasi dan pengujian. Oleh karena itu, kebenaran ilmu dapat digeneralisasi, karena ia diperoleh melalui sejumlah penelitian dan pembuktian, se dangkan pengetahuan belum dapat digunakan untuk proses generalisasi karena ia tidak rnenurut penelitian dan pengkajian lanjutan ${ }^{23}$.

Ilmu atau science dipandang sebuat sistem, sebagaimana dikemukakan oleh Kosso, bahwa :

"Science is a process of assembling an interconnected structure of descriptive claims about nature. The structure and interconnectedness are key. Understanding scientific method requires understanding the links in a broad network of information, some of it from observation and some of it from theory. Science requires coherence among these claims. Lots of pieces must fit together, and no isolated analysis of one idea or one test will result in a good reason to believe a theory." 24

2007.

${ }^{19}$ Tim Dosen Filsafat Ilmu Fakultas Filsafat UGM, Filsafat Ilmu, Yograkarta : Liberty,

${ }^{20}$ Saefullah Wiradipraja,E., Filsafat Ilmu (Revisi), Slide Bahan Mata Kuliah Filsafat Ilmu Program Pascasarjana Unpad/Unisba, tidak diterbitkan, tanpa tahun,hlm.44.

${ }^{21}$ Cecep Sumarna, Filsafat Ilmu : Dari Hakikat Menuju Ilahi, Edisi Revisi, Pustaka Bani Quraisy, 2006. hlm.95.

${ }^{22}$ Ahmad Tafsir, Filsafat Umum : Akal dan Hati Sejak Thales Sampai Capra, Cet.XVI, Bandung : Remadja Rosdakarya, 2008,hhl.16.

${ }^{23}$ Cecep Sumarna, Op.Cit, hlm.95.

${ }^{24}$ Kosso, Peter., A Summary of Scientific Method, USA : Springer,2011,hlm.39. 
(Ilmu adalah proses penyusunan struktur yang saling interkoneksi dalam rangka tuntunan dekripsikan tentang alam. Struktur dan keterkaitan adalah kunci. Memahami metode ilmiah membutuhkan pemahaman keterkaitan dalam jaringan luas informasi, sebagian dari pengamatan dan beberapa dari teori. Ilmu membutuhkan koherensi . Banyak potongan harus sesuai bersama-sama, dan tidak ada analisis terisolasi dari satu ide atau satu tes akan menghasilkan alasan baik untuk mempercaya teori).

Setiap jenis pengetahuan, pada prinsipnya selalu berguna untuk memberikan jawaban terhadap berbagai pertanyaan yang muncul dalam diri seseorang. Pengetahuan selalu memberi rasa puas dengan menangkap tanpa ragu terhadap sesuatu. Pengertian pengetahuan seperti itu telah membedakannya dengan ilmu yang selalu menghendaki penjelasan lebih lanjut dan apa yang sekedar dituntut oleh pengetahuan ${ }^{25}$. Kesan yang muncul atas definisi di atas adalah pengetahuan berbeda dengan ilmu. Pengetahuan adalah sejumlah informasi yang menjadi landasan awal bagi lahirnya ilmu. Tanpa didahului oleh pengetahuan, ilmu tidak akan pernah ada dan mungkin tidak akan pernah lahir.

Pengetahuan pada hakikatnya merupakan segenap apa yang kita ketahui tentang suatu obyek tertentu, termasuk ke dalamnya adalah ilmu, jadi ilmu merupakan bagian dan pengetahuan yang diketahui oleh manusia di samping berbagai pengetahuan lainnya seperti seni dan agama. ${ }^{26}$

The Liang Gie ${ }^{27}$ Istilah ilmu atau science merupakan suatu perkataan bermakna ganda, yaitu mengandung lebih daripada satu arti. Sehingga memakai istilah ilmu, sekurang-kurangnya menyadari arti mana yang dimaksud. Ilmu merupakan sebuah istilah umum untuk menyebut segenap pengetahuan ilmiah yang dipandang sebagai suatu kebulatan. Dalam arti pertama ini ilmu mengacu pada ilmu seumumnya ( science-in general). Arti yang kedua dari ilmu menunjuk pada masing-masing bidang pengetahuan ilmiah yang mempelajari sesuatu pokok tertentu. Dalam arti ini ilmu berarti sesuatu cabang ilmu khusus seperti misalnya antrologi, biologi, georgrafi atau sosiologi.

\footnotetext{
${ }^{25}$ Mundziri, Logika, Jakarta : Rawali Perss, 2000,hlm. 5.

${ }^{26}$ Jujun S.Suriasumantri, Filsafat Ilmu : Sebuah Pengantar Populer, Jakarta : Pustaka Sinar Harapan,2003,hlm.104.

${ }^{27}$ The Liang Gie, Op.Cit.,hlm.85-86.
} 
Berkitan dengan pembedaan tersebut, E. Saefullah Wiradipraja menjelaskan bahwa ${ }^{28}$ Kumpulan pengetahuan untuk dapat disebut sebagai ilmu harus memenuhi syarat-syarat yaitu adanya obyek material (l) dan obyek forma(l). Setiap bidang ilmu, baik ilmu-ilmu khusus atau ilmu filsafat harus memenuhi dua macam obyek tadi. Lebih lanjut dijelaskan pula bahwa, obyek materia adalah sesuatu hal yang dijadikan sasaran pemikiran (Gegenstand), sesuatu hal yang diselidiki/dipelajari. Obyek material mencakup apa saja, baik hal-hal yang konkret (misalnya manusia, tumbuhan, batu) atau hal-hal yang abstrak (misalnya ide-ide, nilai-nilai, kerohanian). Obyek formal adalah cara memandang-meninjau yang dilakukan oleh seorang peneliti terhadap obyek materialnya serta prinsip-prinsip yang digunakannya. Misalnya obyek materia-nya adalah "manusia", dapat ditinjau dari berbagai sudut sehingga ada beberapa ilmu yang mempelajari manusia, yaitu: psikologi, antropologi, sosiologi, dsb. ${ }^{29}$

Obyek forma suatu ilmu tidak hanya memberi keutuhan suatu ilmu, tetapi pada saat yang sama membeda-bedakannya dari bidang-bidang lainnya. Suatu obyek materia dapat ditinjau dari berbagai sudut pandang sehingga menimbul ilmu yang berbeda-beda.

lstilah obyek materia juga sering dianggap sama dengan pokok persoalan/bahasan (subject matter). Pokok persoalan ini perlu dibedakan atas dua $\operatorname{arti}:{ }^{30}$

Pertama, pokok persoalan sebagai bidang khusus dari penyeledik faktual, misal peneliti tentang atom termasuk bidang fisika; tentang klorofil termasuk bidang botani atau biokimia; tentang bawah sadar termasuk bidang psikologi.

Kedua, pokok persoalaan sabagai suatu kumpulan pertanyaan yang saling berhubungan. Anatomi dan fisiologi keduanya bertalian dengan struktur tubuh. Anatomi mempelajari strukturnya, fisiologi mempelajari fungsinya. Kedua ilmu tersebut dapat dikatakan memiliki pokok persoalan yang sama, tapi juga dapat dikatakan berbeda. Anatomi mempelajari tubuh dalam aspeknya yangg statis, fisiologi dalam aspeknya yang dinamis. Perbedaan tersebut dapat diketahui bila

28 Saefullah Wiradipraja,E., Op.Cit,hlm.44.

${ }^{29}$ Ibid,hlm.46.

${ }^{30}$ Ibid,hlm.46-47. 
dikaitkan dengan corak pertanyaan yangg diajukan dan aspek-aspek yang diteliti dari tubuh tersebut.

Berkenaan dengan pengertian obyek materia dan obyek forma ilmu, terdapat perbedaan antara ilmu yang satu dengan yg lainnya. Misalnya objek materianya berupa pohon kelapa. Seorang ahli ekonomi akan mengarah perhatiannya/peninjauannya (obyek forma) pada aspek ekonomi dari pohon kelapa tersebut, berapa harga buahnya, kayunya, atau lidinya kalau dijual. Seorang ahli hukum akan mempertanyakan status kepemilikan pohon tersebut., siapa pemilik sahnya, apakah ditanam di lahannya sendiri atau lahan sewaan, dan sebagainya. Jadi dapat disimpulkan bahwa para ilmuwan yang ahli dibidang disiplin ilmu tertentu menaruh perhatiannya pada salah satu aspek dari obyek materanya. ${ }^{31}$

The Liang $\mathrm{Gie}^{32}$, berpendapat bahwa dari segi maknanya, pengertian ilmu menunjuk pada sekurang-kurangnya tiga hal, yakni pengetahuan, aktifitas dan metode. Dalam hal yang pertama dan ini yang terumum, ilmu senantiasa berarti pengetahuan (knowledge). Dalam arti ilmu sebagai pengetahuan ini, terdapat pemahaman umum bahwa ilmu merupakan suatu kumpulan sistematis dari pengetahuan (Henry W.Johnstone : any sustematic body of knowledge. Ilmu merupakan semua Pengetahuan yang dihimpun dengan perantaraan metode ilmiah (John G.Kemeny: all knowledge collected by means of the scientifis methode).

The Liang Gie ${ }^{33}$ menyatakan arti ilmu yang kedua adalah aktifitas, berkaitan dengan istilah science berasal dari perkataan latin scientia, yang diturukan dari perkataan scire. Scire artinya mengetahui ( to know) atau belajar (to learn). Tetapi pengetahuan sesungguhnya hanyalah hasil atau produk dari sesuatu kegiatan yang dilakukan manusia. Sehingga makna tambahan ilmu sebagai aktifitas (atau suatu proses, yakni serangkaian aktifitas yang dilakukan manusia. Charles Singer merumuskan bahw ilmu adalah proses yang membuat pengetahuan (science is the process which makes knowledge).

\footnotetext{
${ }^{31} \mathrm{Ibid}, \mathrm{hlm} . .48$.

${ }^{32}$ The Liang Gie, Op.Cit,hlm.86-87.

${ }^{33}$ Ibid, hlm. 87
} 
Menurut The Liang Gie ${ }^{34}$, ilmu sebagai metode, disampaikan oleh Harold Titus, bahwa ilmu merupakan suatu metode guna memperoleh pengetahuan yang obyektif dan dapat diperiksa kebenarannya. (a method of obtaining knowledge that is objective and verifiable ).

The Laing $\mathrm{Gie}^{35}$, berkesimpulan bahwa makna ganda dari pengertian ilmu, yang berarti pengetahuan, aktifitas atau metode sesungguhnya tidak saling bertentangan melainkan suatu kesatusan loggis yang mesti ada secara berurutan. Ilmu harus diusahakan dengan aktifitas manusia, aktifitas tersebut harus dilaksanakan dengan metode tertentu dan akhirnya aktifitas metodis tersebut mendatangkan pengetahuan yang sistematis.

The Liang $\mathrm{Gie}^{36}$ memandang ilmu dari tiga sudut, yakni ilmu dapat dihampiri dari arah aktifitas para ilmuwan atau dibahas mulai dari segi metode atau dimengerti sebagai pengetahuan yang merupakan hasil yang sudah sistematis. Ciri pokok ilmu sebagai rangkaian kegiatan manusia atau proses, sebagai tata tertib tindakan pikiran atau prosedur dan sebagai keseluruhan hasil yang dicapai atau produk. Berdasarkan ketiga kategori proses, prosedur dan produk yang semuanya bersifat dinamis (tidak ada yang statis). Dengan demikian pengertian ilmu selengkapnya berarti aktifitas penelitian, metode ilmiah dan pengetahuan sistematis.

The Liang $\mathrm{Gie}^{37}$ menyatakan bahwa pemahaman ilmu yang demikian (aktifitas penelitian, metode ilmiah dan pengetahuan sistematis) mendapat penguatan dari Filsuf Belgia Jean Ladriere bahwa " Science may be regarded as sum of our present knowledge, or as a research activity, or a as a method of acquiring knowledge(Ilmu dapat dipandang sebagai keseluruhan pengetahuan kita dewasa ini atau sebagai suatu aktifitas penelitian, atau sebagai metode untuk memperoleh pengetahuan). Oleh karena itu menurut Jujun S.Suriasumantri, Ilmu merupakan pengetahuan ilmiah ${ }^{38}$

\footnotetext{
${ }^{34}$ Ibid,hlm. 88.

35 Ibid.

${ }^{36}$ Ibid.

37 Ibid.

${ }^{38}$ Jujun S.Suriasumantri, Op.Cit,,hlm.33.
} 
Jujun S.Suriasumantri, ${ }^{39}$ mengutip pendapat Auguste Comte (1798-1857), membagi tiga tingkat perkembangan pengetahuan tersebut di atas ke dalam tahap religius, metafisik dan positif. Dalam tahap pertama maka asas religilah yang dijadikan "postulat ilmiah' sehingga ilmu merupakan deduksi atau penjabatan dan ajaran religi. Tahap kedua orang mulai berspekulasi tentang metafisika (keberadaan) ujud yang menjadi obyek penelaahan yang terbebas dan dogma religi dan mengembangkan sistem pengetahuan di atas dasar postulat metafisik tersebut. Sedangkan tahap ketiga adalah tahap pengetahuan ilmiah(ilmu) di mana asas-asas yang dipergunakan diuji secara positif dalam proses verifikasi yang obyektif.

Tahap positif tersebut merupakan pengaruh paham Positivisme ${ }^{40}$, yakni paham yang "menumbuhkan" pengetahuan dengan bahan ilmu alam. Segala sesuatu yang ada di luar kenyataan atau di luar fakta ditolak. Yang diterima adalah hanyalah yang dapat ditangkap secara inderawi, yang tampak jelas, dan yang dapat diterima oleh akal. Penyelidikan positivisme dan yang juga menjadi tolok ukur kajian objeknya adalah pada pernyataan mengenai yang nyata, yang bermantaat, yang pasti, yang tepat, sebab kajian positivisme adalah terhadap objek sasaran yang dapat diterima akal, menuju pencapaian kemajuan, dan yang berkeseimbangan logis.

\section{PEMBAHASAN}

\subsection{Teori Kebenaran dalam Ilmu Pengetahuan.}

Jujun S.Suriasumantri, ${ }^{41}$ berpendapat bahwa Manusia mempunyai dua kelebihan yang memungkinkan manusia mengembangkan kemampuannya yakni bahasa yang bersifat komunikatif dan pikiran yang mampu menalar. Manusia mempunyai dua kelebihan yang memungkinkan manusia mengembangkan kemampuannya yakni bahasa yang bersifat komunikatif dan pikiran yang mampu menalar. Manusia Hakikat Penalaran merupakan suatu kegiatan untuk menemukan pengetahuan yang benar. Apa yang disebut benar merupakan suatu proses berfikir dalam menarik kesimpulan yang pengetahuan. Manusia pada hakikatnya merupakan makhluk berfikir, merasa, bersikap dan bertindak.

\footnotetext{
${ }^{39}$ Ibid, hlm. 25.

${ }^{40}$ Hartono Kasmadi (et.al), Filsafat Ilmu, Semarang : IKIP Semarang Pess, 1990,hlm.6

${ }^{41}$ Jujun S.Suriasumantri, Op.Cit., ,hlm.42.
} 
Menurut peninjauan Endang Saefudin Anshari, manusia adalah hewan yang berfikir. Berfikir adalah bertanya. Bertanya adalah mencari jawaban. Mencari jawaban adalah mencari kebenaran. Mencari jawaban tentang Tuhan, alam, manusia, artinya kebenaranan tentang Tuhan, alam, manusia. Jadi akhirnya : manusia adalah makhluk pencari kebenaran. ${ }^{42}$

Kebenaran yang dicari manusia, menurut Endang Saefudin Anshari, terdapat tiga teori kebenaran : Teori Korespondensi, Teori Konsistensi, Teori Pragmatis. ${ }^{43}$ Memahami teori kebenaran tersebut dalam rangka mengetahui persyaratannya agar suatu jalan pikiran menghasilkan kesimpulan yang benar. ${ }^{44}$

Teori kebenaran yang pertama adalah Teori Korespondensi, yang eksponen utamanya adalah Bertrand Russell (1872-1970). Bagi penganut teori korespondensi maka suatu pernyataan adalah benar jika materi pengetahuan yang dikandung pernyataan itu berkorespondensi (berhubungan) dengan obyek yang dituju oleh pernyataan tersebut. Maksudnya jika seseorang mengatakan bahwa "Ibu Kota Republik Indonesia adalah Jakarta" maka pernyataan itu adalah benar sebab pernyataan itu dengan obyek yang bersifat faktual yakni Jakarta yang memang menjadi Ibu Kota Republik Indonesia. Sekiranya orang lain yang menyatakan bahwa "Ibu Kota Republik Indonesia adalah Bandung" maka pernyataan itu adalah tidak benar sebab tidak terdapat obyek yang dengan pernyataan tersebut. ${ }^{45}$

Teori Konsistensi adalah suatu teori kebenaran yang mengakui suatu pernyataan dianggap benar bila pernyataan tersebut, konsisten dengan pernyataan sebelumnya. Secara sederhana dapat disimpulkan bahwa berdasarkan teori Konsistensii süatu pernyataan dianggap benar bila pernyataan itu bersifat koheren atau konsisten dengan pernyataan-pernyataan sebelumnya yang dianggap benar. Bila kita menganggap bahwa "semua manusia pasti akan mati" adalah suatu pernyataan yang benar, maka pernyataan bahwa "Si Polan adalah seorang manusia dan si Polan pasti akan mati"46.

\footnotetext{
${ }^{42}$ Endang Saifuddin Anshari,H., Ilmu, Filsafat, dan Agama, Cet.IX, Surabaya : PT Bina Ilmu,2002, hlm.17.

${ }^{43}$ Ibid,hlm. 18.

${ }^{44}$ Jujun S.Suriasumantri, Op.Cit,hlm.55

45 Ibid,hlm.57.

${ }^{46}$ Ibid.
} 
Matematika ialah bentuk pengetahuan yang penyusunannya dilakukan pembuktian berdasarkan teori Konsistensi. Sistem matematika disusun di atas beberapa dasar pernyataan yang dianggap benar yakni aksioma. Dengan mempergunakan beberapa aksioma maka disusun suatu teorema. Di atas teorema maka dikembangkan kaidah-kaidah matematika yang secara keseluruhan merupakan suatu sistem yang konsisten. Plato (427-347 S.M.) dan Aristoteles (384-322 S.M.) mengembangkan teori konsistensi berdasarkan pola pemikiran yang dipergunakan Euclid dalam menyusun ilmu ukurnya.

Kedua teori kebenaran ini yakni teori konsistensi dan teori korespondensi kedua-duanya dipergunakan dalam cara berpikir ilmiah. Penalaran teoretis yang berdasarkan logika deduktif jelas mempergunakan teori koherensi mi. Sedangkan proses pembuktian secara empiris dalam bentuk pengumpulan fakta-fakta yang mendukung suatu pernyataan tertentu mempergunakan teori kebenaran yang lain yang disebut teori kebenaran pragmatis. Teori Pragmatis dicetuskan oleh Charles S. Peirce (1839-1914). Ahli-ahli filsafat ini di antaranya adalah William James (1842-1910), John Dewey (1859-1952), George Herbert Mead (1863-1931) dan C.I. Lewis.

Bagi seorang pragmatis maka kebenaran suatu pernyataan diukur dengan kriteria apakah pernyataan tersebut bersifat fungsional dalam kehidupan praktis hidupan praktis. Artinya, suatu pernyataan adalah benar, jika pernyataan itu atau konsekuensi dan pernyataan itu mempunyai kegunaan praktis dalam kehidupan manusia. Sekiranya ada orang yang menyatakan sebuah teori $\mathrm{X}$ dalam pendidikan, dan dengan teori $\mathrm{X}$ tersebut dikembangkan teknik $\mathrm{Y}$ dalam meningkatkan kemampuan belajar, maka teori $\mathrm{X}$ itu dianggap benar, sebab teori $\mathrm{X}$ ini adalah fungsional dan mempunyai kegunaan.

Pragmatisme bukanlah suatu aliran filsafat yang mempunyai doktrindoktrin filsafati melainkan teori dalam penentuan kriteria kebenaran sebagaimana disebutkan di atas. Kaum pragmatis berpaling kepada metode ilmiah sebagai metode untuk mencari pengetahuan tentang alam ini yang dianggapnya fungsional dan berguna dalam menafsirkan gejala-gejala alamiah.

Kriteria pragmatisme ini juga dipergunakan oleh ilmuwan dalam menentukan kebenaran ilmiah dilihat dalam perspektif waktu. Secara historis maka pernyataan ilmiah yang sekarang dianggap benar suatu waktu mungkin 
tidak lagi demikian. Dihadapkan dengan masalah seperti ini maka ilmuwan bersifat pragmatis selama pernyataan itu fungsional dan mempunyai kegunaan maka pernyataan itu dianggap benar; sekiranya pernyataan itu tidak lagi bersifat demikian, disebabkan perkembangan ilmu itu sendiri yang menghasilkan pernyataan baru, maka pernyataan itu ditinggalkan.

\subsection{Metode Ilmiah Sebagai Jalan Mendapatkan Ilmu Pengetahuan}

Pada dasarnya pengetahuan, menurut Juhaya S. Praja, mencakup tiga macam pengertian: ${ }^{47}$

a. adanya suatu sistem gagasan dalam pikiran,

b. persesuaian antara gagasan itu dengan benda-benda yang seberanya

c. adanya keyakinan persesuaian.

Pengetahuan manusia yang kian hari kian bertambah ini, pada dasarnya bersumber kepada tiga macam sumber berikut, yaitu: ${ }^{48}$

Pertama, pengetahuan yang langsung diperoleh,

Kedua, hasil dari suatu konklusi dan,

Ketiga, pengetahuan yang diperoleh dari kesaksian dan autoritas.

Pengetahuan langsung diperoleh dari dua sumber : sumber ekstern (luar) dan sumber interen (dalam). Contoh yang pertama: seseorang mengetahui adanya api di depannya rnelalui alat indra penglihatannya, adanya bau harum melalui indra pencium. Contoh pengetahuan yang bersumber dari dalam, contohnya seseorang dapat rnengetahui keadaan dirinya, keadaan sedih, gembira, atau marah.

Pengetahuan Konklusi, ialah pengetahuan yang diperoleh melalui penarikan kesimpulan dari data empirik atau inderawi, seperti apabila seseorang mengetahui bahwa di atas sebuah gunung yang tampak di depannya, ada kepulan asap. Dia mengetahui bahwa setiap ada asap pasti ada api yang sedang menyala. Dengan dcniikian, pada tahap ini orang tersebut menarik konklusi bahwa di atas gunung ada api yang menyala.

\footnotetext{
${ }^{47}$ Juhaya S. Praja, Aliran-Aliran Filsafat dan Etika, Jakarta: Kencana,2005 Hlm.6.

48 Ibid.
} 
Pengetahuan Kesaksian dan Autoritas, ialah pengetahuan yang diperoleh melalui kesaksian dari orang lain atau berita orang yang bisa dipercaya. Contohnya : manusia mengetahui adanya Tuhan melalui para Rasul dan KitabNya, seseorang yang sakit pergi berobat ke dokter kepada dokter yang dipercayanya. Dokter tersebut memberi obat, dan obat itu diminumnya. Orang tersebut tidak mengetahui secara ilmiah apakah dapat menyembuhkannya atau tidak.

Pengetahuan yang diperoleh melalui indera dinamakan dengan "pengetahuan indrawi". Setelah diadakan penyelidikan dan eksperimen, maka ilmu tersebut menjadi "ilmu pengetahuan" (science). Apabila seseuatu hal sudah dapat diketahui oleh indera, dieksperimen dan diteliti. ${ }^{49}$

Hartono Kasmadi (et.al) ${ }^{50}$ menyatakan kebenaran ilmu dicari dan dibuktikan dengan persentuhan indera terhadap alam sekitar. Dengan persentuhan itu diterangkan mengapa suatu objek mempunyai corak demikian atau mengapa objek tersebut harus bercorak demikian. Kebenaran ilmu adalah kebenaran yang didapat dengan cara yang mendalam tanpa menghiraukan untuk apa digunakan ilmu itu dalam kehidupan. Jadi yang penting adalah bagaimana diperoleh pengungkapan yang sejelas-jelasnya mengenal pengetahuan itu.

Menurut Ahmad Tafsir, ${ }^{51}$ perkembangan ilmu pengetahuan didorong oleh faham humanisme ialah faham filsafat yang mengajarkan bahwa manusia mampu mengatur dirinya dan alam. Humanisme telah muncul pada zaman Yunani Lama ( Yunani Kuno). Humanisme memunculkan Rasionalisme.Yaitu paham yang mengatakan bahwa akal itulah pencari dan pengukur pengetahuan. Pengetahuan dicari dengan akal, temuannya diukur dengan akal pula. Dicari dengan akal ialah dicari dengan berfikir logis. Diukur dengan akal artinya diuji apakah temuan itu logis atau tidak. Bila logis,benar, bila tidak salah. Dengan akal itulah aturan untuk mengatur manusai dan alam dibuat.

\footnotetext{
${ }^{49}$ Ibid, hlm.8

${ }^{50}$ Hartono Kasmadi (et.al), Op.Cit,hlm.8-9.

51 Ahmad Tafsir, Filsafat Ilmu : Mengurai Ontologi, Epistemologi dan Aksiologi Pengetahuan, Cet.IV Bandung : PT.Remaja Rosdakarya, 2009,hlm.28-34.
} 
Lebih lanjut dijelaskan pula bahwa dengan berfikir logis, ternyata adakalanya temuan akal itu saling bertentangan. Berfikir logis tidak menjamin diperolehnya kebenaran. Padahal aturan itu harus disepakati. Untuk mengatasi hal tersebut muncul alat lain adalah Empirisme. Yaitu paham filsafat yang mengajarkan bahwa yang benar ialah yang logis dan ada bukti empiris.

Empirisme hanya menemukan konsep yang umum. Konsep tersebut belum operasional, karena belum terukur. Jadi masih diperlukan alat lain, yaitu positivisme. Menurut Muhammad Baqir Ash-Shadr 52, makna kata dalam poitivisme berarti gagasan yang kebenaran dan kepalsuannya dapat ditegaskan dalam batas-batas pengalaman indrawi”

Positivisme merupakan paham yang mengajarkan bahwa kebenaran ialah yang logis, ada bukti empirisnya, yang terukur. Terukur inilah sumbangan positivisme. Misalnya air mendidih 100 derajat celcius, besi mendidih 1000 derahat celcius. Ukutan -ukuran ini operasional, kuantitatif, tidak memungkinkan perbedaan pendapat. Dengan positivisme, aturan untuk mengatur manusia dan aturan untuk mengatur alam bersifat pasti dan rinci (operasional).

Ahmad Tafsir ${ }^{53}$ menjelaskan bahwa Positivisme sudah dapat disetujui untuk memulai upaya membuat aturan untuk mengatur manusia dan mengatur alam. Positivisme, mengajukan logikanya, mengajukan bukti empirisnya yang terukur. Tetapi bagaimana caranya? masih memerlukan alat lain. Alat lain itu ialah Metode Ilmiah. Sayangnya, Metode Ilmiah Sebenarnya tidak mengajukan sesuatu yang baru; Metode Ilmiah hanya mengulangi ajaran Positivisme, tetapi lebih operasional. Metode Ilmiah mensyaratkan bahwa, untuk memperoleh pengetahuan yang benar lakukan langkah berikut: logico-hypothetico-verificatif'. Maksudnya, mula-mula buktikan bahwa itu logis, kemudian ajukan hipotesis berdasarkan logika itu, kemudian lakukan pembuktian hipotesis itu secara empiris.

Dengan rumus Metode Ilmiah inilah dibuat aturan tersebut. Metoda Ilmiah merupakan prosedur yang digunakan para ilmuwan meliputi berbagai tindakan

\footnotetext{
${ }^{52}$ Muhammad Baqir Ash-Shadr, Falsafatuna : Pandangan Muhammad Baqir Asdh-Shadr Terhadap Pelbagai Aliran Filsafat Dunia, Terjemahan M.Nur Mufid Bin Ali, Bnadung : Mizan,1995,hlm.59.

${ }^{53}$ Ahmad Tafsir, Op. Cit.,,hlm.33.
} 
pemikiran,pola kerja, langkah-pangkah, dan teknik-teknik untuk memperoleh pengetahuan bagu, mengoreksi atau mengembangkan ilmu pengetahuan yang telah ada secara sistematis. ${ }^{54}$

Metode Ilmiah itu secara teknis dan rinci dijelaskan dalam satu bidang ilmu yang disebut Metode Riset. Metode Riset menghasilkan Model-model Penelitian. Model-model Penelitian inilah yang menjadi instansi terakhir dan memang operasional dalam membuat aturan (untuk mengatur manusia dan alam). Dengan menggunakan Model Penelitian tertentu dilakukan penelitian. Hasil-hasil penelitian itulah berupa tumpukan ilmu pengetahuan dalam berbagai bidang ilmu. Inilah sebagian dari isi kebudayaan manusia.

Sesuai dengan sifat ilmu, demi objektivitas ilmu maka ilmuwan harus bekerja dengan cara ilmiah. Sifat ilmiah dalam ilmu dapat diwujudkan, apabila dipenuhi syarat-syarat yang intinya adalah sebagal berikut:

(1) Ilmu harus mempunyai objek; ini berarti bahwa kebenaran yang hendak diungkapkan dan dicapai adalah persesuaian antara pengetahuan dan objeknya.

(2) ilmu harus mempunyai metode; ini berarti bahwa untuk mencapai kebenaran yang objektif, ilmu tidak dapat bekerja tanpa metode yang rapi.

(3) Ilmu harus sistematik; ini berarti bahwa dalam memerikan pengalaman, objeknya dipadukan secara harmonis sebagai suatu kesatuan yang teratur.

(4) Harus bersifat universal (berlaku umum secara semesta) ini berarti bahwa kebenaran yang diungkapkan oleh ilmu tidak mengenal sesuatu yang bersifat khusus, melainkan kebenaran itu berlaku umum.

Berkaitan dengan hal tersebut, bagi seorang ilmuwan yang melakukan kegiatan ilmiah terdapat persyaratan yang harus dipenuhi antara lain $:{ }^{55}$

\footnotetext{
${ }^{54}$ Saefullah Wiradipraja,E, Op.Cit.,hlm.77.

${ }^{55}$ Saefullah Wiradipraja,E, Op.Cit,hlm.80-81.
} 
Pertama, prosedur ilmiah tertentu agar hasilnya diakui oleh para ilmuwan lainnya, Kedua metode ilmiah yang digunakan, sehingga kesimpulan atau hasil temuannya diterima-baik sementara maupun selamanya oleh para ilmuwan, terutama bidang sejenis. Ketiga diakui secara akademis, karena latar belakang pendidikan yang ditempuh, Keempat harus memiliki kejururan ilmiah-tidak mengklaim hasil temuan orang lain sebagai hasil temuannya. Kelima, harus mempunyai rasa ingin tahu yang besar (coriously), sehingga selalu tertarik pada perkembangan ilmu.

\section{Keterbatasan Ilmu Pengetahuan Sebagai Sarana Mencari Kebenaran}

Terdapat kecemasan dan kerisauan di antara kalangan ilmuwan, yang disatu pihak mereka merujuk pada karya para ilmuwan, yang kini telah memecahkan banyak teka-teki keberadaan alam raya. Sebelumnya hanya bisa dijelaskan dengan menerapkan suatu kekuatan yang tidak diketahui di alam semesta, dengan mengabaikan keberadaan Tuhan (Allah). Tuhan dikatakan tidak lagi mengisi fungsi. Namun di pihak lain ada yang skeptis dengan kondisi tersebut, dengan mengatakan, manusia merasa sendirian di alam semesta yang sangat besar sekali pada waktu dan cukup lama. Hal ini memunculkan prasyarat manusia perlu memahami asal usul kehidupannya. ${ }^{56}$

Keresahan sebagian ilmuwan ini, memunculkan pertanyaan, mampukah manusia dengan agamanya rasio, dapat mengungkapkan rahasia alam semesta ? Einhorn, penulis berkebangsaan swedia, menjelaskan bahwa :

"However, science will not be able to provide all the answers.As early as the 1930s, mathematician Kurt Gödel proved that certain questions will never be able to be answered in scientific formulas or experiments. And Werner Karl Heisenberg, a physicist experimenting with the smaller components of matter, proved that we will never attain full knowledge of every phenomenon in the universe. It is not possible to distinguish completely the observer from the observed (that is, the world around us), which means that our interpretation of the reality all around us will always be subjective and colored". ${ }^{7}$

\footnotetext{
${ }^{56}$ Einhorn, Stefan A., Concealed God : religion, science, and the search for truth, USA: Library of Congress Cataloging-in-Publication Data,2002, hlm.3.

${ }^{57}$ Ibid, hlm. 124
} 
(Namun, ilmu pengetahuan tidak akan mampu menyediakan semua jawaban. Pada awal tahun 1930, matematikawan Kurt Gödel membuktikan bahwa pertanyaan-pertanyaan tertentu tidak akan pernah bisa dijawab dalam formula ilmiah atau eksperimen. Dan Werner Karl Heisenberg, seorang ahli fisika bereksperimen dengan komponen yang lebih kecil dari materi, membuktikan bahwa kita tidak akan pernah mencapai pengetahuan penuh dari setiap fenomena di alam semesta. Hal ini tidak mungkin untuk membedakan sepenuhnya pengamat dari yang diamati (yaitu, dunia di sekitar kita), yang berarti bahwa penafsiran kita tentang realitas di sekitar kita akan selalu subjektif dan berwarna).

Einhorn mencoba mengajukan dua hasil penelitian untuk membuktikan bahwa manusia tidak akan pernah mampu mencapai pengetahuan yang semurna mengenai alam semesta. Hal ini berarti dengan pengetahuan ilmiah manusia tidak mampu mengungkapkan alam semesta dengan paripuran, karena terdapat hal-hal atau kondisi yang tidak dapat dicapai oleh pikiran maupun pengalaman manusia. Ilmu pengetahuan yang diperoleh manusia akan sangat bergantung terhadap penafsiran suatu gejala alam semesta, yang dinamis, sehingga hasil penelitian menjadi subyektif dan bervariasi

Kondisi tersebut dapat dijelaskan dengan buah pikiran dari Jujun S.Suriasumantri, bahwa $:^{58}$

"Tentu saja tidak semua pengetahuan berasal dan proses pelanaran: sebab berpikir pun tidak semuanya berdasarkan penalaran. Manusia bukan semata-mata makhluk yang berpikir: sekadar Homo sapiens yang steril. Manusia adalah makhluk yang berpikir, merasa, mengindera; dan totalitas pengetahuannya berasal dan ketiga sumber tersebut; di samping wahyu: yang merupakan komunikasi Sang Pencipta dengan makhlukNya".

Alam raya termasuk manusia sendiri tidak akan mampu dijelaskan secara paripurna oleh manusia dengan pengetahuan ilmiahnya, karena manusia sebagai subyek bukan hanya makhluk yang dapat berfikir, melainkan juga ada aspek lain dalam jiwa yang terlepas dari pikiran, yaitu merasa dan mengindera. Dengan menggunakan pikiran saja untuk mencari kebenaran alam raya ini, tentunya akan menghasilkan keterbatasan hasilnya. Sehingga Jujun S.Suriasumantri menawarkan totalitas dalam mencari pengetahuan, dengan tetap memperhatikan wahyu, yang merupakan mediasi manusia dengan Sang Pencipta.

58 Jujun S.Suriasumantri, Op.Cit, hlm.39-42. 
Pengakuan eksistensi agama dan luasnya ilmu pengetahuan yang disadari dalam diri manusia juga mengilhami Eisnstein dalam pandangannya tentang "God and Religion" bahwa :

"We are in the position of a little child entering a huge library filled with books in many different languages. The child knows someone must have written those books. It does not know how. It does not understand the languages in which they are written." 59

Inilah pengakuan yang jujur dari seorang Einstein bahwa manusia dan khasanah pengetahuan yang tersebar di alam raya, dibaratkan dengan anak kecil berada dalam perpustakaan (alam semesta), dengan berbagai fenomena yang berada di dalamnya. Manusia semestinya mengetahui bahwa pasti ada yang menciptakan fenomena-fenomena alam tersebut. Namun kebanyakan manusia tidak memahaminya. Hal ini menandakan bahwa meskipun banyak ilmu pengetahuan yang lahir dari pemikiran rasio manusia. Ini tidak berarti manusia telah memahami alam semesta, namun sebenarnya manusia tidak akan mampu memahaminya tatkala hanya menggunakan rasionya. Terkecuali manusia mampu mempercayai sang Khalik-nya.

Hal ini sebagai mana pandangan Tarnas (dalam Herman Soewardi ), bahwa :

" Orang merasa tahu jagad raya, padahal tidak.Tak ada jaminan bahwa orang bisa tahu. Yang disangkanya jagad raya, sebenarnya hanya menunjukkan hubungan hubungan orang dengan jagad raya saja, atau jagad raya sebagai diciptakan oleh pikiran manusia." 60

Keterbatasan manusia ini dalam memahami alam semesta karena dalam mencari ilmu pengetahuan hanya mengandalkan pemikiran manusia, selain itu ditolaknya, sehingga apa yang dihasilkan pemikiran yang dibatasi oleh ruang dan waktu, ada kalanya suatu ketika suatu paradigma ilmu pengetahuan sudah dianggap benar oleh kalangan ilmuwan, namun pada suatu ketika digantikan penemuan lainnya yang lebih memberikan fakta kebenaran. Hal ini disampaikan

59 Rooney, Anne., Einstein : In His Own Words, London :Arcturus Publishing Limited,2006,hlm.107.

${ }^{60}$ Herman Soewardi, Op.Cit., ,hlm.104. 
oleh Thomas S.Kuhn dalam bukunya "The Structure of Scientific Revolution", yang, menyatakan bahwa sebagai berikut :

"But not all theories are paradigm theories. Both during pre-paradigm periods and during the crises that lead to large-scale changes of paradigm, scientists usually develop many speculative and unarticulated theories that can themselves point the way to discovery. Often, however, that discovery is not quite the one anticipated by the speculative and tentative hypothesis. Only as experiment and tentative theory are together articulated to a match does the discovery emerge and the theory become a paradigm. ",61

(Tapi tidak semua teori adalah teori paradigma. Baik selama praparadigma maupun selama periode krisis yang mengarah ke perubahan paradigma skala besar, para ilmuwan biasanya mengembangkan teoriteori spekulatif dan tidak diartikulasikan yang mengarah pada penemuan. Seringkali, bagaimanapun, penemuan yang tidak cukup satu diantisipasi oleh hipotesis spekulatif dan tentatif. Hanya sebagai percobaan dan teori tentatif bersama-sama diartikulasikan untuk mencocokkan apakah penemuan teori muncul dan menjadi paradigma).

Pendapat Thomas S. Kuhn, menandakan bahwa ilmu pengetahuan tidak ajeg. Suatu kebenaran ilmu pengetahuan yang berupa paradigam yang dijadikan pegangan para ilmuwan, dapat dinafikan oleh kebenaran yang lebih mutahir dengan paradigma yang baru, dengan cara memperbaiki paradigma lama atau malah membatalkan paradigma lama. Tidak mustahil dalam hal ini mencul teori baru yang belum pernah diketahui sebelumnnya.

Berkaitan dengan hal tersebut Hartono Kasmadi (et.al) mengungkapkan bahwa :62

"Ada lagi yang perlu disadari, yakni: bahwa ilmu bukanlah hal yang statis, melainkan bergerak dinamis sesuai dengan pengembangan yang diusahakan oleh manusia dalam mengungkap tabir alam semesta ini. Usaha pengembangan tersebut mempunya arti juga bahwa kebenaran yang telah diungkap oleh ilmu tertentu adalah kebenaran yang masih terbuka untuk diuji. Dengan demikian ada kemungkinan bahwa kebenaran yang telah pernah diterima, kelak ditolak karena ditemukan bukti-bukti ilmiah baru yang lebih objektit. Demikianlah, setiap teori atau hukum yang dikemukakan sebagai kebenaran pada dasarnya tidak lebih adalah hipotesis-hipotesis yang senantiasa dapat diuji lagi."

\footnotetext{
${ }^{61}$ Kuhn S.,Thomas., Op Cit.,,hlm.61.

${ }^{62}$ Hartono Kasmadi (et.al), Op.Cit.,hlm.8-9.
} 
Hal ini berarti bahwa kebenaran ilmu pengetahuan yang telah diterima saat ini sebagai kebenaran ilmu pengetahuan, pada hakekaknya merupakan suatu hipotesis yang memungkinkan diobservasi lagi untuk menutupi segala kelemahan atau yang belum terungkap dari suatu ilmu pengetahuan, seperti dikemukan oleh menurut Ferman dan Levin bahwa :

"we have defined "theory" with reference to set of concept. Unlike previous conceptions, theory as consummation of explanation consists of a set interrelated proposition. at leats one of which is testable by means of research. Any proposition subjected to empirical test is referred to as "a hypothesis". ${ }^{63}$

Pernyataan tersebut menandakan bahwa sebenarnya kebenaran ilmu yang diperoleh melalui metoda ilmiah merupakan kebenaran relatif, yang menurut Endang Saifuddin Anshari ${ }^{64}$, kebenaran Relatif adalah "pengetahuan mengenai realitas yang kesesuaiannya tidak lengkap dan tidak sempurna. Menurut Lenin, kebenaran relative ini adalah pencerminan daripada obyek yang relative benar, yang terbatas dari manusia”.

Hal senada disampaikan oleh Kosso, bahwa:

"Scientific method is not very different than what everyone does on a daily basis in coming to know about the world. Respect for evidence and reason are basic common sense and basic scientific method. So, disregarding scientific standards and results in selected aspects of life amounts to disregarding commonsense. This is not to say that scientific method is perfect. It is important to note the limitations and potential misuse of the method. Unrealistic expectations will turn any imperfection into a reason to discount the whole thing. "65

Hal tersebut bermakna bahwa meskipun metoda ilmiah menggunakan bukti-bukti dan rasio untuk menerangkan suatu gejala. Namun kenyataannya, penggunaan bukti dan akal sehat dalam metoda mempunyai keterbatasan dan berpotensi timbulnya penyalahgunaan dalam prakteknya. Oleh karena itu, menggantungkan harapan terhadap ilmu pengetahuan yang mempunyai

${ }^{63}$ Ferman, Gerald S., Jack Levin, Social Science Research: A handbook for Student, USA : John Willey \& Son, 1975,hlm.23.

${ }^{64}$ Endang Saifuddin Anshari,H., Op.Cit.,hlm.21.

${ }^{65}$ Kosso, Peter., Op.Cit.,,hlm.39. 
keterbatasan dan dengan segala dampaknya, merupakan harapan yang tidak realistis.

Dengan keterbatasan metoda ilmiah tersebut, maka tepat apa yang disarankan oleh Couvalis, bahwa :

"I concede that much can be learnt from the critics of science. Science, and indeed scientific method itself, is fallible and has often been an accomplice of repressive traditions. Further, science does not give us knowledge of ethical truths. Thus, many of our important beliefs about science have to be revised in the light of criticism. "66

Pernyataan Couvalis, ini menambah data bahwa terdapat sesuatu yang keliru pada saat ilmuwan menggunakan metoda ilmiahnya dalam ilmu pengetahuan. Tidak dapat dipungkiri juga adanya agenda-agenda tertentu dalam penelitian yang berlabel penelitian ilmiah. Hal lain yang sangat menarik dari kritikan Couvalis ini, disinggungnya kebenaran etis yang sama sekali tidak diperhitungkan dalam metoda ilmiah ini. Akhirnya dia yakin bahwa ilmu pengetahuan yang diperoleh dengan metoda ilmiah perlu direvisi.

\section{PENUTUP}

1. Metode Ilmiah merupakan kelanjutan ajaran Positivisme, tetapi lebih operasional. Metode Ilmiah mensyaratkan dalam memperoleh pengetahuan yang benar dengan pendekatan "logico-hypotheticoverificatif". Metode Ilmiah secara teknis dan rinci dijelaskan dengan Metode Riset yang menghasilkan Model-model Penelitian. Model-model Penelitian yang bersifat operasional digunakan dalam suatu penelitian. Hasil-hasil penelitian itulah berupa ilmu pengetahuan dalam berbagai bidang ilmu.

2. Beberapa Keterbatasan Ilmu Pengetahuan Sebagai Sarana Mencari Kebenaran, antara lain :

a. pengetahuan ilmiah manusia tidak akan mampu mengungkapkan alam semesta dengan paripuran, karena terdapat hal-hal atau kondisi yang

${ }^{66}$ Couvalis, George., The Philosophy Of Science : Science and Objectivity, London : SAGE Publications Ltd, 1997,hlm.8. 
tidak dapat dicapai oleh pikiran maupun pengalaman manusia dengan metoda ilmiahnnya .

b. Tidak semua pengetahuan berasal dari proses pelanaran, dalam berpikir tidak semuanya berdasarkan penalaran. Manusia bukan semata-mata makhluk yang berpikir: sekedar Homo sapiens yang steril. Manusia adalah makhluk yang berpikir, merasa, mengindera; dan totalitas pengetahuannya berasal dari ketiga sumber tersebut; di samping wahyu: yang merupakan komunikasi Sang Pencipta dengan makhlukNya.

c. Manusia dan khasanah pengetahuan yang tersebar di alam raya, dibaratkan dengan anak kecil berada dalam perpustakaan (alam semesta), dengan berbagai fenomena yang berada di dalamnya. Manusia semestinya mengetahui bahwa pasti ada yang menciptakan fenomena-fenomena alam tersebut. Namun kebanyakan manusia tidak memahaminya. Hal ini menandakan bahwa meskipun banyak ilmu pengetahuan yang lahir dari pemikiran rasio manusia. Ini tidak berarti manusia telah memahami alam semesta, namun sebenarnya manusia tidak akan mampu memahaminya tatkala hanya menggunakan rasionya. Terkecuali manusia mampu mempercayai sang Khalik-nya Ilmu pengetahuan tidak ajeg. Suatu kebenaran ilmu pengetahuan yang berupa paradigam yang dijadikan pegangan para ilmuwan, dapat dinafikan oleh kebenaran yang lebih mutahir dengan paradigma yang baru, dengan cara memperbaiki paradigma lama atau malah membatalkan paradigma lama. Tidak mustahil dalam hal ini muncul teori baru yang belum pernah diketahui sebelumnnya.

\section{DAFTAR PUSTAKA}

Abdul Qodir Djaelani, 1993, Filsafat Islam, PT.Bina Ilmu, Surabaya.

Ahmad Tafsir, 2009, Filsafat Ilmu : Mengurai Ontologi, Epistemologi dan Aksiologi Pengetahuan, Cet.IV, PT.Remaja Rosdakarya, Bandung.

Ahmad Tafsir, 2008, Filsafat Umum : Akal dan Hati Sejak Thales Sampai Capra, Cet.XVI, Remadja Rosdakarya, Bandung.

Ali Syari'ati, 1983, Kritik Islam Atas Marxisme, Mizan, Bandung. 
Cecep Sumarna, 2006, Filsafat Ilmu : Dari Hakikat Menuju Ilahi, Edisi Revisi, Pustaka Bani Quraisy, Bandung.

Claxton, Guy., 2005, "Science of The Times" : A 2020 vision of education, dalam Ralph Levinson and, Jeff Thomas (ed.), Science To Day : Problem or crisis?, Taylor \& Francis e-Library, London.

Couvalis, George., 1997, The Philosophy Of Science : Science and Objectivity, SAGE Publications Ltd, London .

Endang Saifuddin Anshari,H., 2002, Ilmu, Filsafat, dan Agama, Cet.IX, PT Bina Ilmu, Surabaya.

Hartono Kasmadi (et.al), 1990, Filsafat Ilmu, IKIP Semarang Pess, Semarang.

Herman Soewardi, 2009, Roda Berputar Dunia Bergulir : Kognisi Bagu Tentang Timbul Tenggelammnya Sivilisasi, Bakti Mandiri, Bandung.

Juhaya S. Praja, 2005, Aliran-Aliran Filsafat dan Etika, Kencana, Jakarta.

Jujun S.Suriasumantri, 2003, Filsafat Ilmu : Sebuah Pengantar Populer, Pustaka Sinar Harapan, Jakarta.

Kosso, Peter., 2011, A Summary of Scientific Method, Springer, USA.

Kuhn, Thomas S., 1970, The Structure of Scientific Revolutions, Second Edition :, The University of Chicago, Chicago.

Muhammad Baqir Ash-Shadr, 1995, Falsafatuna : Pandangan Muhammad Baqir Asdh-Shadr Terhadap Pelbagai Aliran Filsafat Dunia, Terjemahan M.Nur Mufid Bin Ali, Mizan, Bandung.

Mundziri, Logika, 2000, Rajawali Perss, Jakarta.

Saefullah Wiradipraja,E., Filsafat Ilmu (Revisi), Slide Bahan Mata Kuliah Filsafat Ilmu Program Pascasarjana Unpad/Unisba, tidak diterbitkan, tanpa tahun.

The Liang Gie, 2007, Pengantar Filsafat Ilmu, Cet.VII, Liberty, Yogyakarta.

Tim Dosen Filsafat Ilmu Fakultas Filsafat UGM, Filsafat Ilmu, Yograkarta : Liberty, 2007. 